ISSN: 1838-3815 (online) Journal Homepage: https://ojs.deakin.edu.au/index.php/itlge/

\title{
Provocation
}

Subject to Editor review, Provocations are intended to be short and showcase thought, leadership and expert commentary on the future of credentials for work in a disrupted world.

\section{Extending micro-credentials to micro-apprenticeships for the Fourth Industrial Revolution: Enhancing vocational education and training in the post-pandemic's 'new normal'}

\author{
Pi-Shen Seet ${ }^{1}$ and Janice Jones ${ }^{2}$ \\ Corresponding author: Pi-Shen Seet (p.seet@ecu.edu.au) \\ ${ }^{1}$ School of Business and Law, Edith Cowan University, WA. ORCID: 0000-0002-4737-9594 \\ ${ }^{2}$ College of Business, Government and Law, Flinders University, SA. ORCID: 0000-0002-4737-9594
}

As noted in the foreword of this Special Issue, COVID-19 has accelerated the Fourth Industrial Revolution's or Industry 4.0's disruption to the labour market (Kift, 2021). Beyond Industry 4.0 (14.0), the COVID-19 pandemic has accelerated the adoption of digital technologies by enterprises, underscoring the need for workers to continuously upskill their digital competencies in order to remain relevant (Heinonen \& Strandvik, 2021). Besides digitisation, organisations have had to innovate and adopt new business models to adapt to the 'new normal' of surviving and growing beyond the COVID-19 pandemic. In countries that largely relied on skilled migration as an important source of talent, the closure of international borders has restricted mobility of human capital resulting in insufficient skilled employees to meet the current and ever-increasing demand for skills (Guadagno, 2020).

While employers and industry groups have called for a return to opening borders to skilled migrants, seasonal workers and international students, the ongoing struggle of many countries to cope with new COVID-19 variants suggests that international borders will largely remain closed among many countries in the world. When they do open in the future, they will be more restrictive than they used to be (Seet \& Jones, 2021). Although labour shortages are not new, the impact of this talent deficit has been compounded by COVID-19-related snap state border closures, together with international border closures, which constrain domestic and international mobility, and limit employers' access to skills (Seet \& Jones, 2020b).

To cope with the skills challenges in this new environment, and improve the efficiency of skills matching and development, we argue there is a need to develop and make better use of homegrown human capital, albeit in a more flexible and responsive manner. To this end, there exists an opportunity for the vocational education and training (VET) sector to evolve, by extending emerging developments in micro-credentials to micro-apprenticeships. This will enable businesses to

Seet, P-S., \& Jones, J. (2021). Extending micro-credentials to micro-apprenticeships for the fourth industrial revolution: Enhancing vocational education and training in the post-pandemic's 'new normal'. Journal of Teaching and Learning for Graduate Employability, 12(1), 39-43. 
introduce new technologies that are underpinned by new skills, whilst enabling workers to upskill in an ongoing manner, recognising that training is a flexible and continuous process, not a 'set and forget' exercise.

\section{The impact of the pandemic on apprenticeships}

Although the term 'apprenticeship' can be interpreted in a variety of ways, a formal apprenticeship is normally found to display the following characteristics (Fuller \& Unwin, 2013; Smith, 2010): it has a close link to specific occupations; it is part of a training regime established by, or with the approval of, governments; combines both off- and on-the job training; employers are responsible for apprentice development; after the completion of an apprenticeship, the award of a qualification and/or licence and/or some other recognition that enables an occupation to be practised independently.

As a result of lockdowns negatively affecting economic demand and employment, there has been a sharp decline in apprenticeships since the start of the COVID-19 pandemic (Goller \& Wolter, 2021). In Australia, it has been estimated that new apprenticeships will decline by $30 \%$ in the 2 years between 2021 and 2023 (Hurley, 2020).

As such, many governments have focussed on supporting the VET sector during the pandemic (Barabasch \& Keller, 2021). For example, the Australian federal government introduced a Supporting Apprentices and Trainees wage subsidy at the start of the COVID-19 pandemic where eligible employers were able to claim $50 \%$ of an apprentice's gross wage (Feltham \& Keats, 2021). The initial scheme was fully subscribed and had to be extended to meet the overwhelming demand.

However, almost all these supported apprenticeships are in traditional industries such as construction-related trades. In addition, they follow the conventional training system whereby apprentices complete 1-2 years of training with the employer, graduate and are seen to be fully qualified, without any further recognition of the need for ongoing upskilling. This results in skills mismatches. Employers point to a skills deficit as a barrier to innovation and business growth because the VET system does not provide a framework for qualified employees who have completed apprenticeships to continually upgrade their skills in line with new technologies and business models.

\section{What are micro-apprenticeships and why are they important?}

Micro-apprenticeships are a specific form of micro-credentials. Like most micro-credentials, microapprenticeships are mini qualifications in smaller blocks of learning and they can formalise soft and hard skills attained at work, such as teamwork, critical thinking, creativity and problem solving (Johnson, 1997). However, micro-apprenticeships are distinct in that they are specifically related to an apprenticeship model of training. Therefore, micro-apprenticeships are supposed to meet the requirements of apprenticeships as stated above (e.g. training responsibilities are primarily those of the employers instead of VET providers), albeit in a shorter and more flexible delivery mode. Microapprenticeships, hence, have been claimed to allow for apprentices to be rapidly trained to develop their skills by meeting ongoing technology and market changes (Hare, 2021).

The former British Prime Minister, Winston Churchill said, "Never waste a good crisis". The pandemic can serve as a good opportunity for countries that are facing difficulties reforming their VET systems to update their skills and training systems to better prepare them for the changes anticipated as part of 14.0. While Australian firms have tended to rely on sending staff offshore for training in Germany and Japan (two countries that are acknowledged to be ahead of the game) and bringing in experts from abroad to provide on-site training to augment skills and help fill skills gaps (Seet et al., 2019), this is not likely to be a viable option in the near term, given ongoing border closures.

Seet, P-S., \& Jones, J. (2021). Extending micro-credentials to micro-apprenticeships for the fourth industrial revolution: Enhancing vocational education and training in the post-pandemic's 'new normal'. Journal of Teaching and Learning for Graduate Employability, 12(1), 39-43. 
Recognising this, the Business Council of Australia has intensified its call for a more flexible VET training system that emphasises lifelong learning with innovations in micro-credentialing like microapprenticeships (Hare, 2021).

\section{How to make micro-apprenticeships work}

Our research for the National Centre for Vocational Education Research has shown that if Australia is to capitalise on the opportunities in 14.0, it needs to focus on developing new skills in disruptive technologies (Seet et al., 2018). Given employers' preference for a 'top up' qualification or module that builds on existing base qualifications, the opportunity exists for VET providers to develop new micro-apprenticeships. These micro-apprenticeships would incorporate work placements and course offerings tailored to participants and their employers so as to establish a more flexible skills and training system focussed on continuous upskilling that is responsive to the changes in 14.0 technologies and innovations (EY, 2021).

Unlike micro-internships that are often virtual in nature and allow for students to complete their work projects fully online (Freeland, 2019), micro-apprenticeships will normally need high employer involvement and some on-the-job training often at specially developed facilities. This is especially so given the complexity of aligning the training needs of future employees with the rapid changes in 14.0 technologies and innovations. Research indicates that the current VET workforce is perceived to fall short of the requisite 14.0 knowledge base (Seet et al., 2018). This means that there needs to be increased formal and informal initiatives between actors in the 14.0 ecosystem like VET training providers, higher-education institutions, employer organisations, industry and governments (Smith, 2019).

To encourage dissemination and transfer of 14.0 knowledge, collaborations between developers and suppliers of 14.0 technology and VET will need to be encouraged and supported to experiment and test new models and methods. One potential model for wider adoption is that of Swinburne University's 14.0 focussed apprenticeship program (Seet et al., 2018). Trainees undertake part of their VET courses at Swinburne's 'Factory of the Future' facility on advanced modules, followed by short, focussed periods of practising their skills with employers (e.g. Siemens and AiGroup) (Seet \& Jones, 2020a). Another future model is the first nationally recognised qualification in automation, led by Rio Tinto, South Metropolitan TAFE and the Western Australian government (Seet et al., 2019). Rio Tinto committed funds toward the upskilling of out-of-work apprentices affected by COVID-19 for an accredited micro-credential course. The training is delivered in four-day blocks that leads to a 'Working Effectively in an Automated Environment' qualification which then opens up new apprenticeship opportunities for these displaced students at top-tier automation facilities (Rio Tinto, 2020).

\section{Conclusion}

Globalisation has facilitated the use of migration, particularly international migration, to fix skills mismatches and labour shortages in many countries (Yeoh, 2020). The ongoing closure of borders due to the COVID-19 pandemic provides a window of opportunity for a step-change in how countries that would like to transform outdated skills and training systems to incorporate more flexibility that emphasises lifelong learning via micro-credentials like micro-apprenticeships.

In his expert review of the Australian VET system, Stephen Joyce noted the potential for microcredentials to offer more flexible ways of learning and suggested that they will be increasingly relevant for industry as they can help in the delivery of in-time training to meet emerging and urgent skills needs (Department of the Prime Minister and Cabinet, 2019). In the context of VET, microcredentials are seen as short and targeted training products (Department of Education Skills and Employment, 2021) and have been touted as a means to help improve the efficiency of the apprenticeship system. 
Regular upskilling is recognised as essential to future proofing the 14.0 workforce, thus making micro-apprenticeships an increasingly appealing and accessible option for lifelong learning. Microapprenticeships can help fill important skill gaps, such as working with big data, and contribute to workers' capabilities to understand, leverage and realise the potential of technological advancements (Fisher, 2019). However, for these changes to be sustainable, structural barriers (e.g., training packages) to the development of more flexible initiatives like micro-apprenticeships need to be overcome. Through partnering with enterprises to provide upskilling opportunities, VET providers can not only help fill critical skill gaps in the workforce through micro-apprenticeships, but also capitalise on an untapped market of potential students. Employees, in turn, benefit from an indemand skill set, and the ability to equip themselves with a relevant skill set as the world of work continues to evolve.

\section{References}

Barabasch, A., \& Keller, A. (2021). The next steps for apprenticeship. Cedefop/OECD. https://doi.org/10.2801/085907

Department of Education Skills and Employment. (2021). Supporting micro-credentials in the training system. https://www.dese.gov.au/skills-reform/skills-reform-overview/supporting-microcredentials-trainingsystem

Department of the Prime Minister and Cabinet. (2019). Strengthening skills: Expert review of australia's vocational education and training system. https://pmc.gov.au/resource-centre/domestic-policy/vetreview/strengthening-skills-expert-review-australias-vocational-education-and-training-system

EY. (2021). Making Australia a world leading digital economy. Business Council of Australia. https://d3n8a8pro7vhmx.cloudfront.net/bca/pages/238/attachments/original/1619726043/BCA Digital reform agenda_- EY Report - 28 April.pdf?1619726043

Feltham, B., \& Keats, N. (2021). Jobmaker: How the federal budget hiring credit scheme works. NSW: Law Society of New South Wales. https://Isj.com.au/articles/jobmaker-how-the-federal-budget-hiringcredit-scheme-works/

Fisher, J. F. (2019). Micro-internships: Just a gig or a promising gateway? Christensen Institute. https://www.christenseninstitute.org/blog/micro-internships-just-a-gig-or-a-promising-gateway/

Fuller, A., \& Unwin, L. (2013). Apprenticeship and the concept of occupation. http://www.gatsby.org.uk/uploads/education/reports/pdf/apprenticesfullpvs.pdf

Goller, D., \& Wolter, S. C. (2021). "Too Shocked to Search": The Covid-19 shutdowns' impact on the search for apprenticeships. IZA - Institute of Labor Economics Discussion Paper Series. https://ssrn.com/abstract=3846689

Guadagno, L. (2020). Migrants and the COVID-19 pandemic: An initial analysis (Vol. 60). Geneva: International Organization for Migration,.

Hare, J. (2021). Why your next career course should be a micro-apprenticeship. The Australian Financial Review. https://www.afr.com/business-summit/why-your-next-career-course-should-be-a-microapprenticeship-20210308-p578po

Heinonen, K., \& Strandvik, T. (2021). Reframing service innovation: COVID-19 as a catalyst for imposed service innovation. Journal of Service Management, 32(1), 101-112. https://doi.org/10.1108/JOSM-05-2020$\underline{0161}$

Hurley, P. (2020). Impact of coronavirus on apprentices and trainees. Mitchell Institute for Education and Health Policy Victoria University.

Johnson, S. D. (1997). Learning technological concepts and developing intellectual skills. International Journal of Technology \& Design Education, 7, 161-180. https://doi.org/10.1.1.941.5925

Kift, S. (2021). Foreword. Journal of Teaching and Learning for Graduate Employability, 12(1). https://doi.org/10.21153/itlge2021vol12no1art1015

Rio Tinto. (2020). Rio Tinto's partnership with SM TAFE, WA Government wins global award. https://www.businesswire.com/news/home/20201214005887/en/

Seet, P.-S., \& Jones, J. (2020a). Advanced apprenticeships will boost skills for future jobs, but not in time to counter COVID impacts. The Conversation. https://theconversation.com/advanced-apprenticeshipswill-boost-skills-for-future-jobs-but-not-in-time-to-counter-covid-impacts-147113

Seet, P.-S., \& Jones, J. (2020b). There may not be enough skilled workers in Australia's pipeline for a postCOVID-19 recovery. The Conversation. https://theconversation.com/there-may-not-be-enoughskilled-workers-in-australias-pipeline-for-a-post-covid-19-recovery-140061

Seet, P-S., \& Jones, J. (2021). Extending micro-credentials to micro-apprenticeships for the fourth industrial revolution: Enhancing vocational education and training in the post-pandemic's 'new normal'. Journal of Teaching and Learning for Graduate Employability, 12(1), 39-43. 
Seet, P.-S., \& Jones, J. (2021). Migration is a quick fix for skills shortages. Building on Australians' skills is better. The Conversation. https://theconversation.com/migration-is-a-quick-fix-for-skills-shortages-buildingon-australians-skills-is-better-159207

Seet, P.-S., Jones, J., Hoardacre, A.-L., \& Spoehr, J. (2018). The fourth industrial revolution - implications of technological disruption for Australian VET. NCVER. https://www.ncver.edu.au/research-andstatistics/publications/all-publications/the-fourth-industrial-revolution-the-implications-oftechnological-disruption-for-australian-vet

Seet, P.-S., Jones, J., Hoardacre, A.-L., \& Spoehr, J. (2019). Jobs are changing, and fast. Here's what the VET sector (and employers) need to do to keep up. In J. Watson (Ed.), The Conversation Yearbook 2019: 50 Standout Articles from Australia's Top Thinkers (pp. 123-128). Melbourne University Press.

Smith, E. (2010). Apprenticeships. In P. L. Peterson, E. Baker, \& B. McGaw (Eds.), International encyclopedia of education (pp. 312-319). Elsevier Ltd. https://doi.org/https://doi.org/10.1016/B978-0-08-0448947.00774-0

Smith, E. (2019). Apprenticeships and 'future work': Are we ready? International Journal of Training and Development, 23(1), 69-88. https://doi.org/https://doi.org/10.1111/ijtd.12145

Yeoh, B. S. (2020). Temporary migration regimes and their sustainability in times of COVID-19. Geneva: International Labour Organisation for Migration. https://publications.iom.int/system/files/pdf/temporary-migration.pdf 